\title{
A ACUPUNTURA NO CONTROLE DA DOR OROFACIAL
}

Fernanda TIBONI; Daniel BONOTTO

A acupuntura é uma abordagem terapêutica que visa o controle sintomatológico das enfermidades pela estimulação de pontos específicos através da introdução de agulhas. $O$ agulhamento destes locais cria uma desorganização regional, levando a um aumento da microcirculação e a uma estimulação do SNC, com a liberação de endorfinas e outras substâncias com efeito analgésico e antiinflamatório. As condições dolorosas que acometem a região orofacial, principalmente as de origem somática, podem apresentar bons resultados com a técnica de acupuntura. O objetivo deste trabalho é apresentar a acupuntura como modalidade de terapia de suporte no controle das dores orofaciais, através de uma revisão da literatura. 